\title{
An Analysis of Factors Affecting Investor Demand for Initial Public Offerings in Singapore*
}

\author{
Li Li Eng \\ The National University of Singapore, Singapore \\ Hwee Shan Aw \\ The National University of Singapore, Singapore
}

This aritcle investigates the impact of fundamentals of initial public offering (IPO) firms on two categories of investors, large and small investors. In the decision to purchase IPOs, the demand by large investors is positively associated with earnings yield, firm size and underpricing, and negatively associated with book-to-market ratio. Large investor demand is higher for issues denominated in the local currency (Singapore dollars) than issues denominated in foreign currencies. In contrast, the demand by small investors is negatively associated with earnings yield, firm size and underpricing. Small investor demand is also lower for issues denominated in Singapore dollars than issues denominated in foreign currencies (JEL: G14, G32, M41).

Keywords: initial public offerings, fundamentals, small investors, large investors.

\section{Introduction}

This article examines whether investors' demand for initial public offerings (IPOs) is determined by the fundamentals of the firm. During times of IPO fervor, it is often questioned whether retail investors take the companies' fundamentals into account before participating in initial public offerings. For instance, optimistic market sentiment in Singapore at the end of 1996 drove investors to pump in $\$ 1.83$ billion of application

*This article is based in part on the BBA(Honors) thesis of the second author. We thank the two reviewers and the Editor-in-Charge for their comments and suggestions that greatly improved this article, and the National University of Singapore Research Fund for financial support. All errors remain our responsibility.

(Multinational Finance Journal, 2000, vol. 4, no. 1\&2, pp. 133-153)

(CMultinational Finance Society, a nonprofit corporation. All rights reserved.

DOI: $10.17578 / 4-1 / 2-6$ 
moneys for only $\$ 82.52$ million worth of shares available in 1997's first five public offers (The Straits Times, January 27, 1997). This IPO fever is in stark contrast to the situation six months earlier where several issues were undersubscribed and closed at discounts to their offer price at the close of the first trading day.

The earnings number has been shown to possess information content by articles that examine investor reaction via the share price (example, Ball and Brown, 1968), and via volume of trading (example, Beaver, 1968). The price test reflects changes in the expectations of the market as a whole while the volume test reflects changes in the expectations of individual investors (Beaver, 1968). Recent articles using the price test show that valuation of initial public offerings is positively associated with the earnings signal (Feltham, Hughes, and Simunic, 1991; Clarkson and Simunic, 1994). The price test is one approach to examining the information content of the earnings number in the prospectus of new issues. The alternative approach to examining information content of earnings of companies applying for listing is the share volume test. This article adopts this approach in examining the impact of earnings and other fundamentals on demand for new shares by investors.

Unlike other markets, most of the application schedules for new issues by various categories of investors are publicly available for companies applying for listing on the Stock Exchange of Singapore (SES). The demand for new issues can be constructed from these application schedules. Using these data, this article examines the factors that influence the demand for new share issues in Singapore with reference to two broad categories of share applications - the applications for small lots, and the applications for large lots. These application sizes proxy for small and large investor demands, respectively. Specifically, this article investigates whether the relationship between fundamentals and small investors' demand is different than that between fundamentals and large investors' demand.

The results indicate that the demand for IPO shares by small investors is negatively associated with earnings yield, firm size and underpricing. Small investors also have a lower demand for issues denominated in the local currency (Singapore dollars) than issues denominated in foreign currencies. In contrast, the demand for IPO shares by large investors is positively associated with earnings yield, firm size and underpricing, and negatively associated with book-to-market 
ratio. Large investors have a higher demand for issues denominated in Singapore dollars than issues denominated in foreign currencies.

This article is organized as follows: section II discusses the listing requirements and institutional features of the Singapore IPO market. Section III reviews theoretical models of initial public offerings and factors related to valuation. The hypotheses are in section IV and a detailed description of the data and methodology is contained in section V. Section VI presents the test results and findings. Section VII contains the conclusion.

\section{Institutional Features}

This section presents some of the key features of the listing requirements and institutional features of the Singapore IPO market. These are described in considerable detail in Koh and Walter (1989) and Lee, Taylor and Walter (1996). Public companies in Singapore are listed on one of two boards: the Main Board or Sesdaq (Stock Exchange of Singapore Dealing and Automated Quotation). Firms seeking listing on the Main Board of the SES must fulfil certain criteria. They must have been in operation for at least five years, show profits in the last three years, disclose past and future dividends, show healthy working capital, debt-equity ratio and asset backing. The listing requirements for Sesdaq are less stringent than those for the Main Board. Sesdaq consists mainly of small and medium-sized companies that do not have the requisite record to qualify for the Main Board. A Sesdaq company can apply to be upgraded to the Main Board after two years if it meets the requirements for the Main Board.

The firm commitment method is used in underwriting in Singapore. ${ }^{1}$ The firm that invites the public to apply for its shares must state the offer price in the prospectus. As of 1991, firms may choose to offer a portion of their shares under the Dutch auction system. ${ }^{2}$ This allows professional investors to price their applications for the required number of shares according to their valuation. However, these firms that choose the Dutch auction system must still set aside a significant proportion of

1. The other underwriting method is the best efforts method.

2. See Asian Finance, October 15, 1991, pp. 46, 48. 
the issue based on a predetermined price for subscription by small investors.

In the event that the share issue is oversubscribed, the underwriter will allocate the shares in an even-handed manner to all share applicants. Underwriters do not allocate shares to preferred clients as practised in the United States, where offer prices are based on indications of interest made prior to the issue (Hanley and Wilhelm, 1995). In Singapore, share applications are grouped in ranges according to the number of shares applied for. For each range, the underwriter then designates the balloting ratio, and the number of shares to be allotted for each successful application. The balloting ratio for each range is the probability of success that each application will be allotted the shares. All applicants for a particular number of shares in an initial public offering have an equal probability of receiving an allocation. New rules set by the SES in 1990 require at least 30 percent of the shares in a new issue to be allocated to "small" applicants, that is, those who apply for 500 to 10,000 shares. $^{3}$ This rule creates a bias in favour of small investors as evident in Koh and Walter (1989) and Lee, Taylor and Walter (1999). Koh and Walter (1989) show that the probability of receiving an allocation of shares for a 1,000-share application (0.35) is more than twice the probability of success $(0.16)$ when 1 million shares are applied for. Lee, Taylor and Walter (1999) find that application and allocation proportions differ across the four classes of investors. Based on their sample, large investors who applied for 250,000 shares and above, on average, account for approximately half the applications though they are allocated only 28 percent. In contrast, small investors who applied for 1,000 shares constitute an average of 12 percent of the applications, but they receive an average of 32 percent. Their results show that inferences drawn from an analysis of the allocation decisions are in stark contrast to those arising from the application patterns. Therefore, total underlying demand may not be evident from the allocation data. The implication is that the underlying demand is more accurately reflected in the investors' application strategies rather than in the allocation patterns determined by the underwriters and issuers.

Details of the rationing process, which is conducted by way of a public ballot, are publicly disclosed for most initial public offerings. This

3. See Business Times, February 22, 1990. 
disclosure allows for the estimation of the demand schedule, and for the researcher to observe the application pool for an issue. This article employs 63 initial public offerings with sufficient disclosure to reconstruct the application proportions based on the estimated demand for two groups of investors classified as small and large according to share application size.

\section{Literature Review}

An initial public offering involves four groups - the issuing firm, the underwriter/investment bank, the initial buyers and the larger set of investors in the secondary market. These groups have varying amounts of information regarding the issuing firm. It may be the case that the issuer has better information on the value of the security than do the investors or underwriters (example, Downes and Heinkel, 1982; Ritter, 1984; Hwang, 1988). Alternatively, it may be the case that the underwriters possess information superior to the issuer and investors (example, Baron, 1982; Rees, 1987). It may also be the case that the most important informational asymmetry may arise within a market group rather than between different groups (example, Rock, 1986). That is, investors are differentiated by their levels of information about the true value of the issue into "informed investors" and "uninformed investors", with the former having perfect information. As a result of this asymmetry, informed investors compete with uninformed investors only for "good" issues, creating adverse selection in which the probability of obtaining shares in "bad" issues is higher for uninformed investors. This adverse selection proposed by Rock (1986) is analyzed by Ritter (1984), Beatty and Ritter (1986), Koh and Walter (1989), Carter and Manaster (1990), McStay (1992), Keloharju (1993) and Lee, Taylor and Walter $(1996 ; 1999)$.

This information asymmetry creates uncertainty in the investor who will then tend to underprice the issue. Baron (1982), Rock (1986) and Grinblatt and Hwang (1989) present models that suggest a positive relation between the degree of investor uncertainty over issue value and the extent of underpricing. Empirical evidence between value uncertainty and underpricing is provided in Ederington (1974), Bear and Curley (1975), Beatty and Ritter (1986), Miller and Reilly (1987), 
Johnson and Miller (1988), and Carter (1992). Firms may also use underpricing as a signal of quality (Welch, 1989). However, Garfinkel (1993) does not find evidence to support the signaling hypothesis.

While underpricing of an issue is related to uncertainty, the valuation of the security is also related to the fundamentals of the firm. Since Graham and Dodd's (1934) seminal work on determining the fundamental worth of a company, various articles have examined the link between accounting numbers and valuation. For example, Ball and Brown (1968) demonstrate the usefulness of accounting income by showing the association between the accounting income number and stock price. Ou and Penman (1989) show that current accounting numbers can be used to predict the probability of the direction of future earnings, and this prediction of future earnings is associated with future returns. Chan, Hamao and Lakonishok (1993) examine the relationship between four fundamental variables and expected returns in the Japanese stock market. The four variables are earnings yield, cash flow yield, size (market capitalization of equity) and book-to-market ratio. They find that the book-to-market ratio and cash flow yield are associated with expected returns.

Prior research examines the link between the value of securities and fundamentals of the firm (the price test). This article extends prior research by using the volume test on initial public offerings. That is, this article examines the link between demand for new issues and fundamentals of the firm.

\section{Hypotheses}

To test the effect of fundamentals on the demand for new issues, this article employs three variables in Chan, Hamao and Lakonishok (1993), namely, earnings yield, firm size and book-to-market ratio. ${ }^{4}$ If certain fundamentals exhibit greater power in explaining stock (initial) returns, it is expected that there would be the same directional relationships between 'fundamentals and expected return' and 'fundamentals and

4. The test for cash flow yield is omitted as cash flow per share is highly correlated with earnings per share (correlation coefficient of .97). The high correlation is predictable as cash flow per share is defined simply in the company prospectuses as earnings per share add depreciation (per share). 
demand for new issues'. It is expected that informed demand for initial public offerings would be stronger for firms with higher earnings yield and book-to-market ratio, and weaker for larger firms. This understanding of the fundamentals is expected of the institutional investors. Institutional investor demand is not observable in Singapore, and in this article large investor demand is used as a proxy for this variable.

While it might be expected that institutional investors would base their investment decisions on analysis of the fundamentals of the firm, it is often reported in the Singapore press that retail (or small) investors do not pay enough attention to the fundamentals. This article examines the observation of market analysts who suggest that fundamentals do not influence the demand of retail (or small) investors. Investor identity is not observable, and hence retail investor demand is proxied by small investors. If small investors are not aware of the fundamentals of the IPO firms, their demand for shares in the IPO firms will not be affected by earnings yield, book-to-market ratio, and firm size.

One other factor that may influence the demand for the share issue is underpricing. Rock (1986) argues that in an initial public offering, the well-informed investors participate in the good (underpriced) issues but withdraw from the bad (overpriced) issues. Consequently, uninformed investors are disadvantaged in that they get a smaller proportion of the good issues, but a larger proportion of the bad issues. Rock shows that initial public offerings must be underpriced to attract uninformed investors to the issue. In the analysis, underpricing is included as a control variable.

Following the discussion presented earlier, it is hypothesized that large investors engage in some sort of fundamental analysis as huge capital is required upfront when they apply for large amounts of shares. In contrast, small investors pay little attention to fundamentals when they apply for shares. This is especially true when the market for initial public offerings is bullish, and everyone hopes to make quick profits out of this "IPO fever". This article next compares the extent to which fundamentals impact the purchasing decisions of large and small investors. Thus, it is hypothesized that the association between demand and the fundamental variables (earnings yield, book-to-market ratio and firm size) is different between large and small investors. 


\section{Data and Research Methodology}

\section{A. Sample}

The sample consists of 63 initial public offerings listed on the SES Main Board and Sesdaq from January 1993 through January 1997. During this period, there were 111 initial public offerings. Forty-eight initial public offerings are excluded from the sample for the following reasons:

Six initial public offerings were undersubscribed and they did not provide sufficient details to allow for the demand schedule to be reconstructed.

A further 14 initial public offerings were oversubscribed but there were insufficient details disclosed to estimate the demand from the application patterns.

The remaining 28 initial public offerings either offered 1000 or 5000 shares for subscription in the Fixed Price category which prohibited the reconstruction of the demand schedule for the two classes of investors used in this article.

There were 12 issues in foreign currencies. Out of these 12, 11 of the issues were priced in US dollars and one was denominated in HK dollars. For the 63 initial public offerings included in the sample, there was sufficient information to estimate the total demand schedule for the issue, according to the size of applications.

The data sources include company prospectus, company files, SES Journals and The Straits Times. The company files are manually searched to extract details pertaining to application patterns and actual number of shares that are available for the public, after excluding those shares that are reserved for the employees and business associates of the issuing companies. ${ }^{5}$ Details regarding each firm's fundamentals are obtained from the company prospectus. These include historical earnings per share (EPS), book value of assets, book value of equity, offer price and issue size (in number of shares) of the initial public offering. The first day's closing price and the SES All-share index are obtained from SES Journals and The Straits Times.

5. Typically, approximately ten percent of the shares offered are reserved for priority allocation. 


\section{B. Regression Models}

The following regression models are used to examine the factors affecting large and small investors' demand for initial public offerings:

$$
\begin{aligned}
d_{i, y}= & \beta_{0}+\beta_{1} E / P_{i}+\beta_{2} \log \operatorname{SIZE}_{i}+\beta_{3} B / M_{i} \\
& \beta_{4} U N D P R C_{i}+\beta_{5} \text { OFFTYPE }_{i}+\varepsilon,
\end{aligned}
$$

and

$$
\begin{aligned}
d_{i, y}= & \beta_{0}+\beta_{1} E / P_{i}+\beta_{2} \log \operatorname{SIZE}_{i}+\beta_{3} B / M_{i}, \\
& \beta_{4} \text { LTGAIN }_{i}+\beta_{5} \text { OFFTYPE }_{i}+\varepsilon
\end{aligned}
$$

where

$d_{i, y} \quad$ Application proportion for company $i$ 's initial public offering by each defined category of investors expressed as a percentage of the total demand; $y=$ small, or large investors respectively.

$\mathrm{E} / P_{i} \quad$ Earnings yield of company $i$ measured by its earnings per share divided by issue price per share.

$\log S I Z E_{i} \quad$ Size of company $i$ measured by the logarithm of its total assets.

$B / M_{i} \quad$ Book-to-market ratio of company $i$ measured by the book value of its equity (including paid-in capital and reserve accounts) per share divided by its issue price per share.

$U N D P R C_{i} \quad$ Underpricing of company $i$ given by the closing price on the first day of listing minus the issue price divided by the issue price. ${ }^{6}$

OFFTYPE $_{i}$ Issue type of company $i$ 's initial public offering; indicator variable with the value one representing a Singapore dollar denominated issue and zero for a foreign currency denominated issue.

LTGAIN $_{i} \quad$ Cumulative abnormal returns over 36 months from the

6. Expectation of underpricing is not observable at the time investors apply for shares. For the purpose of this article, investors' expectation of underpricing is measured by realized underpricing. 
first month of listing.

This article examines two classes of investors according to their application sizes, namely small and large. A small investor is defined as one who applies for less than 10,000 shares (or 10 lots), and a large investor is one who applies for 100,000 shares (100 lots) or more. This article does not make any hypothesis about the class of investors who apply for 10,000 shares and above but less than 100,000 shares (10 to 99 lots), that is, the medium investors. The demand by the two classes of investors is estimated from the application schedule provided. Lee, Taylor and Walter (1999) describe the method of estimating investor demand in their appendix. The formulation for demand obtained from Lee, Taylor and Walter (1999) is given below: ${ }^{7}$

$$
D_{i}=\frac{A P_{i} \times A S \times I B_{i} \times L R_{i}}{N A_{i}}
$$

where

$D_{i} \quad$ the demand for shares within the range $i$,

$A P_{i} \quad$ the percentage of total shares allocated to investors with applications within the range $i$,

$A S$ the number of shares available to the public for subscription,

$I B_{i} \quad$ the inverse of the balloting ratio for applications within the range $i$,

$L R_{i} \quad$ the low point of the application range $i$, and

$N A_{i} \quad$ the number of shares allotted per successful application within the range $i$.

The share allocation for a sample firm, Jade Technologies Singapore Limited's initial public offering is given in the Appendix.

\section{Results and Findings}

\section{A. Descriptive Statistics}

Panel A of table 1 presents descriptive statistics of the 63 initial public

7. The notation and definition for the formulation for demand follow those in Lee, Taylor and Walter (1999). 
TABLE 1. Descriptive Statistics of Fundamentals of the Sample Firms

\begin{tabular}{|c|c|c|c|c|c|c|c|}
\hline Variables & Mean & \multicolumn{2}{|c|}{ Std. Dev. } & \multicolumn{2}{|c|}{ Median } & Min & Max \\
\hline \multicolumn{8}{|c|}{ A. All Firms (observations $=63$ ) } \\
\hline Earnings yield & .085 & .033 & & .090 & & .014 & .244 \\
\hline Total assets (S\$’00) & 74,983 & 92,120 & \multicolumn{2}{|c|}{48,322} & 6,812 & & 489,532 \\
\hline $\begin{array}{l}\text { Shareholders' equity } \\
\left(\mathrm{S} \${ }^{\prime} 000\right)\end{array}$ & 30,102 & 46,465 & 16,5 & 555 & 2,816 & & 336,590 \\
\hline Book-to-market & .347 & \multicolumn{2}{|l|}{.183} & \multicolumn{2}{|l|}{.312} & .094 & 1.152 \\
\hline Underpricing & .3665 & \multicolumn{2}{|c|}{.3491} & \multicolumn{2}{|c|}{.2525} & -.0882 & 1.3123 \\
\hline Issue size (in millions) & 35.962 & \multicolumn{2}{|l|}{29.808} & \multicolumn{2}{|l|}{23.900} & 2.640 & 135.000 \\
\hline Issue price $(\mathrm{S} \$)$ & .79 & \multicolumn{2}{|l|}{.76} & .60 & & .25 & 4.16 \\
\hline \multicolumn{8}{|c|}{ B. Singapore $\$$-denominated Firms (observations $=51$ ) } \\
\hline Earnings yield & .078 & .026 & \multicolumn{2}{|r|}{.079} & \multicolumn{2}{|r|}{.014} & .129 \\
\hline Total assets (S\$'000) & 51,495 & 52,475 & 29,7 & 797 & 6,812 & & 241,190 \\
\hline $\begin{array}{l}\text { Shareholders' equity } \\
\text { (S\$’000) }\end{array}$ & 17,913 & 13,424 & 14,0 & 097 & 2,816 & & 57,695 \\
\hline Book-to-market & .350 & .179 & & .315 & & .094 & 1.152 \\
\hline Underpricing & .3841 & .3434 & & .29 & & -.0882 & 1.2133 \\
\hline Issue size (in millions) & 32.692 & 26.825 & & 22 & & 2.640 & 120.545 \\
\hline Issue price $(\mathrm{S} \$)$ & .55 & .17 & & .55 & & .25 & .90 \\
\hline C. Foreign Currency-de & ominated Firms & is (observatior & $\mathrm{ns}=1$ & & & & \\
\hline Earnings yield & .112 & .045 & & .101 & & .065 & .244 \\
\hline Total assets (S\$’00) & 174,810 & 147,940 & 103,8 & 880 & 45,905 & & 489,532 \\
\hline $\begin{array}{l}\text { Shareholders' equity } \\
(\mathrm{S} \$ 000)\end{array}$ & 81,902 & 87,942 & 52,4 & 455 & 16,555 & & 336,590 \\
\hline Book-to-market & .333 & .207 & & .291 & & .140 & .900 \\
\hline Underpricing & .2848 & .3807 & & .2124 & & -.0645 & 1.3123 \\
\hline Issue size (in millions) & 51.121 & 38.919 & & 43 & & 7.5 & 135.000 \\
\hline Issue price $(\mathrm{S} \$$ ) & 1.80 & 1.31 & & 1.17 & & .54 & 4.16 \\
\hline
\end{tabular}

Note: Earnings yield= Earnings per share divided by issue price; Total assets $=$ Fixed assets + Current assets;Shareholders' equity = Shareholders' Capital + Reserves + Retained Earnings; Book-to-market $=$ Book value of equity per share divided by issue price per share; Underpricing $=($ First day closing price - Issue price $) /$ Issue price, Issue size $=$ Number of shares offered in initial public offering.

offerings used in this article. Table1, panels B and $\mathrm{C}$ present descriptive statistics for the sub-samples of Singapore \$-denominated firms and foreign currency-denominated firms, respectively. 
TABLE 2. Descriptive Statistics of Application Proportions by Type of Investor Categories for the Sample of 63 Initial Public Offerings That Were Listed on the SES Main Board and Sesdaq between January 1993 and January 1997

\begin{tabular}{lllll}
\hline Investor & Mean & Std. Dev. & Median & Min
\end{tabular}

A. All Firms (number of observations $=63$ )

$\begin{array}{lrrrrr}\text { Small } & 17.50 & 12.28 & 13.04 & 2.99 & 52.59 \\ \text { Medium } & 21.40 & 9.17 & 21.57 & 3.59 & 59.80 \\ \text { Large } & 61.10 & 17.07 & 64.10 & 19.24 & 91.76\end{array}$

B. Singapore \$-denominated Firms (number of observations $=51$ )

$\begin{array}{llrrrr}\text { Small } & 16.32 & 11.80 & 11.66 & 2.99 & 52.59 \\ \text { Medium } & 21.74 & 9.25 & 21.57 & 3.59 & 59.80 \\ \text { Large } & 61.94 & 16.53 & 65.99 & 25.19 & 91.76\end{array}$

C. Foreign Currency-denominated Firms (number of observations =12)

\begin{tabular}{lrrrrr} 
Small & 22.51 & 13.53 & 21.98 & 2.48 & 47.92 \\
Medium & 19.95 & 9.06 & 19.47 & .048 & 32.84 \\
Large & 57.54 & 19.59 & 61.97 & 19.24 & 80.65 \\
\hline
\end{tabular}

Note: All statistics are represented as percentages. Small investors are defined as those who apply for 1,000 to 9,000 shares. Medium investors are defined as those who apply for 10,000 to 99,000 shares. Large investors are defined as those who apply for 100,000 shares or more. Proportion for investor group

$$
y=\frac{\text { Estimated number of shares applied by group } y * 100 \%}{\text { Total number of shares applied for in initial public offering }}
$$

$y$ being small, medium or large investors.

Table 2 presents the descriptive statistics of the share proportions applied for by the three categories of investors (small, medium and large) based on application size. It is observed that on average, small investors represent 17.5 percent of the total applications although they 
would be allotted at least 30 percent $^{8}$ of the total shares available to the public. Medium investors account for 21.4 percent of the applications, and large investors 61.1 percent. The substantial differences in application and allocation proportions may give rise to a false picture of the real demand for initial public offerings. Hence in this article, demand is measured by application proportions instead of allocation proportions. On average, the demand by small investors is more volatile as compared to the large investors. The coefficient of variation is .686 for demand by small investors (standard deviation of 12 percent, mean of 17.5 percent) and .278 for demand by large investors (standard deviation of 17 percent, mean of 61.1 percent). Table 2, panels B and C present the descriptive statistics of the share proportion applied for by small, medium and large investors for the sub-samples of Singapore \$-denominated firms and foreign currency-denominated firms, respectively. The data also shows that small investors exhibit a greater preference for foreign currency-denominated issues than large investors.

\section{B. Impact of Fundamentals and Underpricing on Investor Demand}

First, the factors that explain large investor demand are analyzed. The results of the multiple regression analysis of the application proportions for large investors on earnings yield, firm size, book-to-market ratio, underpricing, and issue type are presented in table 3 . The coefficient on earnings yield, $\beta_{1, L}$, is 1.7485 ( $t$-statistic $=2.18$ ). The coefficient on firm size, $\beta_{2, L}$, is $.053(t$-statistic $=2.39)$. The coefficient on book-to-market ratio, $\beta_{3, L}$, is -0.2467 ( $t$-statistic $\left.=-2.02\right)$. Underpricing is positively related with large investor demand; $\beta_{4, L}=0.2917$ ( $t$-statistic $\left.=5.51\right)$. Large investor demand is positively and significantly associated with the currency denominator; $\beta_{5, L}=.1369(t$-statistic $=2.30)$. To summarize, large investors' application for IPO shares is positively associated with earnings yield, and negatively associated with book-to-market ratio. Large investor demand for IPO shares is higher for bigger firms, when there is underpricing, and for local denominated issues.

Next, the model for small investor demand is examined. Table 3 shows that the coefficient on earnings yield is significantly negative; $\beta_{1, S}$

8. The revised allocation/balloting ratio that came into force in February 1990 is in line with SES's move to diversify share ownership in favor of small investors. See Business Times, February 22, 1990. 
TABLE 3. Multiple Regression of Investor Demand on Fundamentals of Firm and Underpricing

\begin{tabular}{lcc}
\hline Variables & Large Investors & Small Investors \\
\hline Intercept & -.6024 & $1.0035^{* * *}$ \\
E/P & $(-1.4)$ & $(3.55)$ \\
& $1.7485^{* *}$ & $-1.6627 * * *$ \\
$\operatorname{logSIZE}$ & $(2.18)$ & $(-3.17)$ \\
& $.053^{* *}$ & $-.0312 * *$ \\
B/M & $(2.39)$ & $(-2.14)$ \\
& $-.2467 * *$ & 0.1013 \\
UNDPRC & $(-2.02)$ & $(1.27)$ \\
& $.2917 * * *$ & $-.1571 * * *$ \\
OFFTYPE & $(5.51)$ & $(-4.49)$ \\
Adjusted $R^{2}$ & $.1369 * *$ & $-.1477 * * *$ \\
$F$-statistic & $(2.3)$ & $(-3.77)$ \\
number of observations & .373 & .4017 \\
\hline
\end{tabular}

Note: *Significant at the $10 \%$ level in a two-tailed test. **Significant at the $5 \%$ level in a two-tailed test. ${ }^{* * *}$ Significant at the $1 \%$ level in a two-tailed test. The regressions are based on remaining observations after deleting observations that have missing values and outliers (those with an absolute value for the studentised residual greater than three or Cook's distance measure greater than one). The model estimated is:

$$
d_{\mathrm{i}, \mathrm{y}}=\beta_{0}+\beta_{1} E / P_{\mathrm{i}}+\beta_{2} \log S I Z E_{i}+\beta_{3} B / M_{i}+\beta_{4} U N D P R C_{\mathrm{i}}+\beta_{5} O F F T Y P E_{i}+\mathcal{E}
$$

$=-1.6627(t$-statistic $=-3.17)$. The coefficient on firm size is negative and significant; $\beta_{2, S}$ is -.0312 ( $t$-statistic $\left.=-2.14\right)$. The coefficient on book-to-market ratio is not significant; $\beta_{3, S}$ is .1013 (t-statistic $=1.27$ ). The negative coefficients on earnings yield and firm size suggest that the small investors are utilizing the information differently than large investors. The non-significant coefficient on book-to-market ratio suggests that small investors do not pay attention to this fundamental of the IPO firms when applying for IPO shares. The results indicate that underpricing is negatively associated with small investor demand. The underpricing coefficient, $\beta_{4, S}=-.1571(\mathrm{t}$-statistic $=-4.49)$ is significant at the 1 percent level. The coefficient on currency denominator is significantly negative; $\beta_{5, S}=-.1477(t$-statistic $=-3.77)$. Small investor 
demand is associated with less underpriced issues, consistent with Rock's (1986) model of winners' curse. Empirically, Michaely and Shaw (1994) show that underpricing is significantly less in the IPOs of Master Limited Partnerships because they draw few institutional investors, and hence are perceived to be subjected less to the adverse selection problem. Finally, small investors' application for shares is lower for local denominated issues than foreign denominated issues.

The earnings yield coefficients for large and small investor demand are opposite in signs. New issues with high earnings yield attract large shareholders. The opposite is true for the small investors whose demand is directed toward issues with lower earnings yield.

The firm size coefficients for large and small investor demand are also opposite in signs. Large investors apply for more shares in larger firms. Small investors' applications are higher for shares in small firms.

The coefficients for underpricing in both regression results for large and small investors are statistically significant but of opposite signs. This is consistent with past empirical results that a relation exists between demand responsiveness and expected underpricing (example, Rock, 1986; Koh and Walter, 1989; Lee, Taylor and Walter, 1996; 1999). Demand by large investors is positively and significantly associated with underpricing. On the contrary, the evidence suggests that small (uninformed) investors appear to concentrate more of their demand on issues that have less underpricing.

The offer type coefficient is also opposite in signs for the two categories of investors. Large investor demand is higher for local denominated issues, but small investor demand is proportionately higher for foreign denominated issues. It appears that earnings yield, firm size, underpricing and offer type are major determinants of demand for new issues.

\section{Impact of Fundamentals and Long-term Gains on Investor Demand}

In this specification, underpricing $(U N D P R C)$ is replaced by long-term gains $(L T G A I N)$ as in equation 2. Table 4 shows that the demand of large investors is negatively and significantly associated with long-term returns; $\beta_{4, L}=-.0593(t$-statistic $=-2.31)$. The demand of small investors for IPO shares is positively and significantly associated with 36 -month cumulative returns; $\beta_{4, S}=.0315(t$-statistic $=2.13)$. The results 
TABLE 4. Multiple Regression of Investor Demand on Fundamentals of Firm and Long Term Performance

\begin{tabular}{lcc}
\hline Variables & Large Investors & Small Investors \\
\hline Intercept & -.0428 & $.7205^{* *}$ \\
EIP & $(-.08)$ & $(2.38)$ \\
& 1.1821 & $-1.3162^{* * *}$ \\
$\operatorname{logSIZE}$ & $(1.38)$ & $(-2.68)$ \\
& .028 & -.0187 \\
B/M & $(1.02)$ & $(-1.17)$ \\
& -.0821 & -.0102 \\
LTGAIN & $(-.56)$ & $(-.12)$ \\
& $-.0593^{* *}$ & $.0315^{* *}$ \\
OFFTYPE & $(-2.31)$ & $(2.13)$ \\
& $.1375^{*}$ & $-.1496^{* * *}$ \\
Adjusted $R^{2}$ & $(1.85)$ & $(-3.48)$ \\
$F$-statistic & .0814 & .2746 \\
number of observations & 2.010 & 5.240 \\
\hline
\end{tabular}

Note: *Significant at the $10 \%$ level in a two-tailed test. $* *$ Significant at the $5 \%$ level in a two-tailed test. $* * *$ Significant at the $1 \%$ level in a two-tailed test. The regressions are based on remaining observations after deleting observations that have missing values and outliers (those with an absolute value for the studentised residual greater than three or Cook's distance measure greater than one).The model estimated is:

$$
d_{\mathrm{i}, \mathrm{y}}=\beta_{0}+\beta_{1} E / P_{\mathrm{i}}+\beta_{2} \log S I Z E_{i}+\beta_{3} B / M_{i}+\beta_{4} L T G A I N_{\mathrm{i}}+\beta_{5} O F F T Y P E_{i}+\mathcal{E}
$$

are interestingly different to the results for underpricing. It would appear that demand for IPO shares by small investors is impacted negatively by the degree of initial underpricing but positively by longterm gains, while demand by large investors is affected in the opposite way. These contrasting results may be explained by the negative correlation between underpricing and long-term gains $(r=-.1459)$. If large investors are primarily interested in earning high initial returns, then, given the negative correlation of underpricing and long-term gains, their demand would be negatively associated with issues that have higher long-term gains.

\section{Z-Tests for Difference Between Population Parameters}

It is postulated that, on average, large investors rely more on 
fundamentals in their purchasing decisions of initial public offerings as compared to the small investors. This article tests whether the coefficients on earnings yield, firm size and book-to-market ratio are different between the large and small investors, i.e., $\beta_{1, \mathrm{~L}} \neq \beta_{1, \mathrm{~S}} ; \beta_{2, L} \neq$ $\beta_{2, S}$; and $\beta_{3, L} \neq \beta_{3, S}$.

The test statistic,

$$
Z_{X}=\frac{\beta_{X, L}-\beta_{X, S}}{S_{p}(1 / n+1 / m)^{1 / 2}},
$$

and

$$
S_{p}^{2}=\frac{n \times S_{L}^{2}+m \times S_{s}^{2}}{n+m-2},
$$

where

$\beta_{X, L}$ the beta coefficients for the regression of large investor demand; $x=1,2$, and 3 as defined in equation 1 ;

$\beta_{X, S}$ the beta coefficients for the regression of small investor demand; $x=1,2$, and 3 as defined in equation 1 ;

$S_{p}{ }^{2} \quad$ the unbiased pooled estimator of the common variance $\mathrm{s}^{2}$;

$S_{L} \quad$ the standard error of the beta coefficient for the regression of large investor demand;

$S_{S} \quad$ the standard error of the beta coefficient for the regression of small investor demand;

$n \quad$ the sample size for regression of large investor demand;

$m \quad$ the sample size for regression of small investor demand.

The Z-statistics for the test of differences in the coefficients in table 3 are obtained. The Z-statistic for the test of differences in the coefficients on earnings yield is 27.592 , significant at the 1 percent level. ${ }^{9}$ Large investors pay more attention to earnings yield than small investors. The Z-statistic for the test of differences in the coefficients on firm size is 24.616 , significant at the 1 percent level. The Z-statistic for the test of differences in the coefficients on book-to-market ratio is

9. At the 1 percent significance level, the null hypothesis is rejected if $|Z|>2.33$. Similarly, at the 5 percent and 10 percent significance level, the null hypothesis is rejected if $|Z|>1.645$ and $|Z|>1.28$, respectively. 
-18.570 , significant at the 1 percent level. It is expected that large investors demand would be more positively associated with book-tomarket ratio than small investors demand, but the results show otherwise.

\section{Conclusion}

Companies applying for listing on the Stock Exchange of Singapore (SES) routinely provide details of how the shares are allocated when the issues are oversubscribed. This disclosure is sufficiently detailed to allow the application schedule for an initial public offering to be reconstructed. For a sample of 63 initial public offerings listed on the SES between January 1993 and January 1997, this article investigates the factors that may determine the demand for new issues. In particular, this article is interested in determining whether there are differences in the factors that influence the share application decisions of small and large investors.

The results of this article provide some insights into the determinants that contribute to new issues demand across the different investor classes. Small investors are defined as those individuals who apply between 1,000 and 9,000 shares, and large investors are defined as those who apply for 100,000 shares or more. The results indicate that small investor demand is negatively associated with earnings yield and firm size. The other fundamental, book-to-market ratio, does not influence the demand of small investors. On the contrary, large investor demand is positively associated with earnings yield and firm size, and negatively associated with book-to-market ratio.

Further, small investor demand is higher for less underpriced issues and issues denominated in foreign currency. The negative relation between underpricing and uninformed demand (small investor demand) is consistent with the winners' curse (Rock, 1986). However, small investor demand is higher for issues that perform well in the long-run. The effects of underpricing, offer type and long-term performance on large investor demand are again in contrast to the results for small investor demand. The demand of large investors is higher for more underpriced issues and issues denominated in the local currency. However, the demand of large investors is negatively related with long- 
term performance of the IPOs.

To summarize, the findings bear two interesting implications. First, large investor demand is higher for issues that have higher earnings yield, higher underpricing, but perform less well in the long-run. Small investors take the opposite view on earnings yield, and they apply for stocks that are underpriced less but do better in the long-run. It is expected that earnings performance would be positively related with the long-term equilibrium prices of stocks, but an intriguing observation is a relation in the opposite direction.

Second, the negative relation between underpricing and small investor demand corroborates Rock's (1986) model, and the findings in Koh and Walter (1989). This implies subsequent allocation of underpriced shares is lower to small investors as shown in Koh and Walter.

APPENDIX. Share Allocation for a Sample Firm

\begin{tabular}{lccc}
\hline $\begin{array}{l}\text { Range of offer } \\
\text { shares applied } \\
\text { for('000) }\end{array}$ & $\begin{array}{l}\text { Balloting } \\
\text { ratio }\end{array}$ & $\begin{array}{l}\text { Shares alloted } \\
\text { per successful } \\
\text { application ('000) }\end{array}$ & $\begin{array}{l}\text { Percent of total } \\
\text { shares available } \\
\text { to the public }\end{array}$ \\
\hline 1 & $2: 50$ & 1 & 21.50 \\
2 to 9 & $3: 50$ & 1 & 38.95 \\
10 to 49 & $4: 50$ & 1 & 23.80 \\
50 to 99 & $5: 50$ & 1 & 3.60 \\
100 to 499 & $5: 50$ & 2 & 7.05 \\
500 to 999 & $6: 50$ & 4 & 2.10 \\
1,000 to 4,999 & $6: 50$ & 6 & 2.70 \\
5,000 and above & $10: 50$ & 12 & 0.30 \\
& & & 100 \\
\hline
\end{tabular}

\section{References}

Ball, R., and Brown, P. 1968. An empirical evaluation of accounting income numbers. Journal of Accounting Research 6: 159-178.

Baron, D. 1982. A model of the demand for investment banking advising and distribution services for new issues. The Journal of Finance 37: 955-976.

Bear, R., and Curley, A. 1975. Unseasoned equity financing. Journal of Financial and Quantitative Analysis 37: 213-232. 
Beatty, R., and Ritter, J. 1986. Investment banking, reputation, and the underpricing of initial public offerings. Journal of Financial Economics 15: 213-232.

Beaver, W. 1968. The information content of annual earnings announcements. Journal of Accounting Research (Supplement 1968): 67-92.

Carter, R. 1992. Underwriting reputation and repetitive public offerings. Journal of Financial Research 15: 341-354.

Carter, R., and Manaster, S. 1990. Initial public offerings and underwriter reputation. The Journal of Finance 45: 1045-1067.

Chan, L.K.C.; Hamao, Y.; and Lakonishok, J. 1993. Can fundamentals predict Japanese stock returns? Financial Analysts Journal (July-August): 63-69.

Clarkson, P., and Simunic, D. 1994. The association between audit quality, retained ownership, and firm-specific risk in U.S. vs. Canadian IPO markets. Journal of Accounting and Economics 17: 207-228.

Downes, D., and Heinkel, R. 1982. Signaling and the valuation of unseasoned new issues. The Journal of Finance 37: 1-10.

Ederington, L. 1974. The yield spread on new issues of corporate bonds. The Journal of Finance 29: 1531-1543.

Feltham, G.; Hughes, J.; and Simunic, D. 1991. Empirical assessment of the impact of auditor quality on the valuation of new issues. Journal of Accounting and Economics 14: 375-399.

Garfinkel, J. 1993. IPO underpricing, insider selling and subsequent equity offerings: Is underpricing a signal of quality? Financial Management 22: 7483.

Graham, B., and Dodd, D. 1934. Security Analysis. New York: McGraw-Hill.

Grinblatt, L., and Hwang, C. 1989. Signalling and the pricing of new issues. The Journal of Finance 44: 393-420.

Hanley, K., and Wilhelm, W. 1995. Evidence on the strategic allocation of initial public offerings. Journal of Financial Economics 37: 239-257.

Hwang, C.Y. 1988. Signalling in a new issue market. Ph.D. Dissertation, UCLA.

Johnson, J., and Miller, R. 1988. Investment banker prestige and the underpricing of initial public offerings. Financial Management (Summer): 1929.

Keloharju, M. 1993. The winner's curse, legal liability, and the long-run price performance of initial public offerings in Finland. Journal of Financial Economics 34, 251-277.

Koh, F., and Walter, T. 1989. A direct test of Rock's model of the pricing of unseasoned issues. Journal of Financial Economics 23: 251-272.

Lee, P. J.; Taylor, S.; and Walter, T. 1996. Expected and realised returns for Singaporean IPOs: Initial and long-run analysis. Pacific-Basin Finance Journal 4: 153-180.

Lee, P. J.; Taylor, S.; and Walter, T. 1999. IPO underpricing explanations: Implications from investor application and allocation schedules. Journal of 
Financial and Quantitative Analysis 34: 425-444.

McStay, K. 1992. The Efficiency of New Issue Markets. New York: Garland Publishing, Inc.

Michaely, R., and Shaw, W.H. 1994. The pricing of initial public offerings: Tests of adverse-selection and signaling theories. Review of Financial Studies 7: 279-319.

Miller, R., and Reilly, F. 1987. An examination of mispricing, returns, and uncertainty for initial public offerings. Financial Management (Summer): 33-38.

Ou, J.A., and Penman, S.H. 1989. Financial statement analysis and the prediction of stock returns. Journal of Accounting and Economics 11: 295-329.

Rees, R. 1987. The theory of principal and agent: Part 1. Surveys in the Economics of Uncertainty. New York: Basil Blackwell.

Ritter, J. 1984. Signaling and valuation of unseasoned new issues: A comment. The Journal of Finance 34: 1231-1237.

Rock, K. 1986. Why new issues are underpriced. Journal of Financial Economics 15, 187-212.

Welch, I. 1989. Seasoned offerings, imitation costs, and the underpricing of initial public offerings. The Journal of Finance 44: 421-449. 